Original Research Article

\title{
Effect of amlodipine on blood glucose level in euglycemic and streptozotocin induced diabetic Albino rats and its pharmacodynamic interaction with glibenclamide
}

\author{
Manju Gari, Rati Ranjan Debbarma, Lakhan Majhee*, Subhankar Choudhury
}

\begin{abstract}
Department of Pharmacology and Therapeutics, Rajendra Institute of Medical Sciences, Ranchi, Jharkhand, India
\end{abstract}

Received: 26 April 2017 Accepted: 24 May 2017

*Correspondence to:

Dr. Lakhan Majhee,

Email: drlakahn35@gmail.com

Copyright: (C) the author(s), publisher and licensee Medip Academy. This is an openaccess article distributed under the terms of the Creative Commons Attribution NonCommercial License, which permits unrestricted noncommercial use, distribution, and reproduction in any medium, provided the original work is properly cited.

\begin{abstract}
Background: Diabetes is one of the largest global health emergencies of the $21^{\text {st }}$ century and its co-existence with hypertension is frequent. These conditions often require polypharmacy with possible risk of drug interaction. This study is conducted to investigate the effect of amlodipine on blood glucose level in euglycemic and diabetic rats and its pharmacodynamic interaction with glibenclamide.

Methods: Rats were divided into six groups of 6 rats in each group. Group 1 and 3 were non-diabetic given $1 \%$ Gum acacia and amlodipine respectively. Group 2, 4, 5 and 6 were made diabetic by using nicotinamide and streptozotocin injection intra peritoneally and given $1 \%$ Gum acacia, glibenclamide, amlodipine and amlodipine + glibenclamide respectively for the period of 28 days. Fasting Blood Glucose (FBG) levels were measured before induction of diabetes, $72 \mathrm{hrs}$ after the induction, on day $0,7^{\text {th }}, 14^{\text {th }}, 21^{\text {st }}$ and $28^{\text {th }}$ day.

Results: Amlodipine produced no significant effect on FBG level in nondiabetic rats but in diabetic rats statistically significant hyperglycemia were observed on day $21^{\text {st }}$ and $28^{\text {th }}$ of study with the ' $p$ ' value $(<0.05)$. Glibenclamide treated rats shows better controlled FBG level throughout study than concomitant administration of glibenclamide with amlodipine. Significant rise in blood FBG level with ' $\mathrm{P}$ ' value $(<0.05)$ were observed in amlodipine + glibenclamide treated group on $21^{\text {st }}$ and $28^{\text {th }}$ day of study.

Conclusions: This study suggest amlodipine produce no effect on the FBG level of normal rats but causes significant hyperglycemia in diabetic rats. Hypoglycemic effect of glibenclamide gets blunted when co-administered with amlodipine.
\end{abstract}

Keywords: Amlodipine, Diabetes, Drug interactions, Glibenclamide

\section{INTRODUCTION}

Diabetes mellitus is a group of metabolic disorders characterized by hyperglycemia resulting from defects in Insulin secretion, Insulin action or both. ${ }^{1}$ It is a multifactorial disorder. Among the different types the Type 2 Diabetes has most frequent occurrence and consists of about $90 \%$ of all the cases of diabetes. ${ }^{2}$ According to the International Diabetes Federation (IDF) diabetes is one of the largest global health emergencies of the $21^{\text {st }}$ century. The number of people living with diabetes worldwide is approximately 415 million in 2015 and is expected to rise to 642 million by $2040 .^{3}$
The co-existence of hypertension and diabetes is frequent. ${ }^{4}$ Importantly, hypertension in patients with diabetes causes a significant increase in the risk of vascular complications and both conditions predispose to chronic kidney disease. ${ }^{5,6}$ To prevent associated microvascular and macrovascular morbidity and mortality both hypertension and diabetes should be diagnosed early and treated aggressively. ${ }^{7-10}$ Polytherapy requires for proper management of these cases but this increases the risk of drug-drug interactions. Pharmacodynamic interactions affect either the pharmacologic efficacy or the magnitude of side effects of a drug without affecting its plasma levels. ${ }^{11}$ 
Sulfonylurea drugs like glibenclamide used for the treatment of Type $2 \mathrm{DM}$ acts by closing ATP sensitive $\mathrm{K}+$ channels and thus result in increased $\mathrm{Ca}^{2+}$ influx and therefore increase insulin release in pancreatic the $\beta$ - cell, hence decreasing blood glucose level. ${ }^{12}$

Amlodipine is a long acting 1, 4 dihydropyridine derivative Calcium channel antagonist, which is frequently used for the management of hypertension with or without Type 2 diabetes. ${ }^{13}$ Amlodipine blocks voltage dependent $\mathrm{Ca}^{2+}$ channels and inhibits the influx of $\mathrm{Ca}^{2+}$ into the cells, not only decreasing the concentration of cytoplasmic $\mathrm{Ca}^{2+}$ directly but also decrease the $\mathrm{Ca}^{2+}$ release from intracellular stores. ${ }^{14}$ An increase in cytosolic calcium is essential for the initiation of insulin secretion by glucose and other nutrients; preventing $\mathrm{Ca}^{2+}$ influx by removal of extracellular $\mathrm{Ca}^{2+}$ or by pharmacologic blockade of voltage - dependent $\mathrm{Ca}^{2+}$ channels may blunt nutrient - induced insulin secretion.

Literature review suggest that concomitant use of calcium channel blockers with Sulfonylurea in patients of Type 2 DM, may reduce their antidiabetic efficacy, while some other studies suggests that Amlodipine therapy has no association with clinically significant changes in routine laboratory parameters like plasma glucose, serum potassium etc. ${ }^{15,16}$

Hence this study was taken up to investigate the effect of amlodipine on blood glucose level in euglycemic and streptozotocin induced diabetic albino rats and its pharmacodynamic interaction with glibenclamide.

\section{METHODS}

The study was carried out in the Department of Pharmacology and Therapeutics, Rajendra Institute of Medical Sciences, Ranchi, Jharkhand, India. Healthy male Wister rats weighing between 150-250gms were selected. The animals were kept in clean and dry cages with 12:12 hours light-dark cycle at room temperature and humidity. They were allowed to acclimatize to the available housing condition for 2 weeks before the initiation of experiment and were fed with standard laboratory diets and water ad libitum.

\section{Drugs used}

- $\quad$ Tab. Amlodipine Besylate 5mg (Amlopress), Cipla Limited, Kumrek, India.

- Tab. Glibenclamide 5mg (Daonil) Sanofi India Limited, Ankleshwar.

- $\quad$ Nicotinamide $100 \mathrm{gm}$ powder, Animed, Kolkata

- $\quad$ Streptozotocin 250mg powder, HIMEDIA, Mumbai

\section{Induction of diabetes}

Diabetes was induced by single intraperitoneal injection nicotinamide $(120 / \mathrm{kg})$ followed by injection of freshly prepared streptozotocin $(60 \mathrm{mg} / \mathrm{kg})$ after 15 minutes.
Nicotinamide prevents complete destruction of pancreatic beta cells by streptozotocin and thereby produces condition similar to Type 2 DM. ${ }^{17}$

Following $72 \mathrm{hrs}$ of induction, diabetes was confirmed by measuring the fasting blood glucose (FBG) level. The rats having FBG levels between $250-300 \mathrm{mg} / \mathrm{dl}$ were selected for this study.

\section{Group allocation and drug treatment}

Study rats were divided into six groups with 6 animals in each. Dose calculation was done by multiplying the standard human dose with the conversion factor for rat (0.018) to get the desired dose for $200 \mathrm{gm}$. rat. ${ }^{18,19}$ Doses for each rat were then individualized as per their body weight. Drugs were administered orally with help of a gavage tube once daily for 28 days between 08:00-9:30 a.m.

Table 1: Grouping and dosages.

\begin{tabular}{|lll|}
\hline Groups & Drug used & Rat doses \\
\hline Non diabetic (Control) & $1 \%$ gum acacia & $10 \mathrm{ml} / \mathrm{kg}$ \\
\hline Diabetic (Control) & $1 \%$ gum acacia & $10 \mathrm{ml} / \mathrm{kg}$ \\
\hline $\begin{array}{l}\text { Non diabetic } \\
\text { (Amlodipine) }\end{array}$ & Amlodipine & $5 \mathrm{mg} / \mathrm{kg}$ \\
\hline $\begin{array}{l}\text { Diabetic } \\
\text { (Glibenclamide) }\end{array}$ & Glibenclamide & $5 \mathrm{mg} / \mathrm{kg}$ \\
\hline Diabetic (Amlodipine) & Amlodipine & $5 \mathrm{mg} / \mathrm{kg}$ \\
\hline $\begin{array}{l}\text { Diabetic (Amlodipine+ } \\
\text { Glibenclamide) }\end{array}$ & $\begin{array}{l}\text { Amlodipine+ } \\
\text { Glibenclamide }\end{array}$ & $5+5 \mathrm{mg} / \mathrm{kg}$ \\
\hline
\end{tabular}

For estimation of FBG rats were kept overnight fasting with free access to water and measured before the induction of diabetes as well as on day $0,7^{\text {th }}, 14^{\text {th }}, 21^{\text {st }}$, and $28^{\text {th }}$ of the study. Blood samples were collected from the tail vein of rats and FBG was measured with the help of Glucometer (Gluco-check), Care bio medical, Mumbai.

\section{Statistical analysis}

All the data were expressed as mean $\pm \mathrm{SD}$ and were analyzed by using one way ANOVA followed by Post hoc analysis using Tukey's HSD (honestly significant difference) test. $\mathrm{P}$ value $<0.05$ was considered statistically significant.

\section{RESULTS}

Table 2 shows there are no significant difference in the FBG level between Group 1 and 3 throughout the study period.

Table 3 shows significant increase in FBG level in Group 5 in comparison to Group 2 on $21^{\text {st }}$ and $28^{\text {th }}$ day of study $\mathrm{p}$ value $(<0.05)$. 
Table 2: Comparing Mean FBG between Group 1 (Non-Diabetic control) and Group 3 (Non-Diabetic with Amlodipine).

\begin{tabular}{|lllll|}
\hline $\begin{array}{l}\text { Fasting } \\
\text { blood } \\
\text { glucose }\end{array}$ & Group 1 & Group 3 & $\begin{array}{l}\text { Mean } \\
\text { difference }\end{array}$ & $\begin{array}{l}\text { P } \\
\text { value }\end{array}$ \\
\hline Day 0 & $\begin{array}{l}79.17 \pm \\
4.79\end{array}$ & $\begin{array}{l}78.17 \pm \\
6.08\end{array}$ & 1.00000 & 1.000 \\
\hline Day 7 & $\begin{array}{l}85.33 \pm \\
3.39\end{array}$ & $\begin{array}{l}87.17 \pm \\
5.60\end{array}$ & 1.83333 & 0.993 \\
\hline Day 14 & $\begin{array}{l}84.17 \pm \\
2.32\end{array}$ & $\begin{array}{l}88.83 \pm \\
5.49\end{array}$ & 4.66667 & 0.694 \\
\hline Day 21 & $\begin{array}{l}83.50 \pm \\
2.59\end{array}$ & $\begin{array}{l}87.67 \pm \\
3.14\end{array}$ & 4.16667 & 0.680 \\
\hline Day 28 & $\begin{array}{l}81.17 \pm \\
3.54\end{array}$ & $\begin{array}{l}86.50 \pm \\
2.43\end{array}$ & 5.33333 & 0.243 \\
\hline
\end{tabular}

Table 3: Comparing Mean FBG between Group 2 (Diabetic control) and Group 5 (Diabetic with Amlodipine).

\begin{tabular}{|lllll|}
\hline $\begin{array}{l}\text { Fasting } \\
\text { blood } \\
\text { glucose }\end{array}$ & Group 2 & Group 5 & $\begin{array}{l}\text { Mean } \\
\text { difference }\end{array}$ & $\begin{array}{l}\text { P } \\
\text { value }\end{array}$ \\
\hline Day 0 & $\begin{array}{l}258.33 \pm \\
7.45\end{array}$ & $\begin{array}{l}262.17 \pm \\
6.18\end{array}$ & 3.83333 & 0.914 \\
\hline Day 7 & $\begin{array}{l}268.67 \pm \\
9.54\end{array}$ & $\begin{array}{l}271.50 \pm \\
5.17\end{array}$ & 2.83333 & 0.954 \\
\hline Day 14 & $\begin{array}{l}271.33 \pm \\
8.09\end{array}$ & $\begin{array}{l}276.67 \pm \\
4.76\end{array}$ & 5.33333 & 0.565 \\
\hline Day 21 & $\begin{array}{l}274.17 \pm \\
9.04\end{array}$ & $\begin{array}{l}283.50 \pm \\
3.27\end{array}$ & 9.33333 & 0.027 \\
\hline Day 28 & $\begin{array}{l}278.67 \pm \\
7.15\end{array}$ & $\begin{array}{l}290.83 \pm \\
4.67\end{array}$ & 12.16667 & 0.000 \\
\hline
\end{tabular}

Table 4: Comparing Mean FBG between Group 2 (Diabetic control) and Group 4 (Diabetic with Glibenclamide).

\begin{tabular}{|lllll|}
\hline $\begin{array}{l}\text { Fasting } \\
\text { blood } \\
\text { glucose }\end{array}$ & Group 2 & Group 4 & $\begin{array}{l}\text { Mean } \\
\text { difference }\end{array}$ & $\begin{array}{l}\text { P } \\
\text { value }\end{array}$ \\
\hline Day 0 & $\begin{array}{l}258.33 \pm \\
7.45\end{array}$ & $\begin{array}{l}260.33 \pm \\
8.33\end{array}$ & 002.00000 & 0.995 \\
\hline Day 7 & $\begin{array}{l}268.67 \pm \\
9.54\end{array}$ & $\begin{array}{l}93.83 \pm \\
3.66\end{array}$ & 174.83333 & 0.000 \\
\hline Day 14 & $\begin{array}{l}271.33 \pm \\
8.09\end{array}$ & $\begin{array}{l}90.33 \pm \\
5.16\end{array}$ & 181.00000 & 0.000 \\
\hline Day 21 & $\begin{array}{l}274.17 \pm \\
9.04\end{array}$ & $\begin{array}{l}80.17 \pm \\
1.47\end{array}$ & 194.00000 & 0.000 \\
\hline Day 28 & $\begin{array}{l}278.67 \pm \\
7.15\end{array}$ & $\begin{array}{l}79.33 \pm \\
2.34\end{array}$ & 199.33333 & 0.000 \\
\hline
\end{tabular}

Comparison of Group 4 rats which were treated with glibenclamide with Group 2 shows consistency in reducing FBS level throughout the study period as depicted in Table 4. In comparison to Group 4 rats,
Group 6 has showed significant increase in FBG level on day $21^{\text {st }}$ and $28^{\text {th }}$ as depicted in Table 5.

Table 5: Comparing Mean FBG between Group 4 (Diabetic with Glibenclamide) and Group 6 (Diabetic with Amlodipine + Glibenclamide).

\begin{tabular}{|lllll|}
\hline $\begin{array}{l}\text { Fasting } \\
\text { blood } \\
\text { glucose }\end{array}$ & Group 4 & Group 6 & $\begin{array}{l}\text { Mean } \\
\text { difference }\end{array}$ & $\begin{array}{l}\text { P } \\
\text { Value }\end{array}$ \\
\hline Day 0 & $\begin{array}{l}260.33 \pm \\
8.33\end{array}$ & $\begin{array}{l}265.67 \pm \\
6.41\end{array}$ & 5.33333 & 0.731 \\
\hline Day 7 & $\begin{array}{l}93.83 \pm \\
3.66\end{array}$ & $\begin{array}{l}97.50 \pm \\
4.76\end{array}$ & 3.66667 & 0.874 \\
\hline Day 14 & $\begin{array}{l}90.33 \pm \\
5.16\end{array}$ & $\begin{array}{l}99.83 \pm \\
5.88\end{array}$ & 9.50000 & 0.060 \\
\hline Day 21 & $\begin{array}{l}80.17 \pm \\
1.47\end{array}$ & $\begin{array}{l}108.17 \pm \\
5.64\end{array}$ & 28.00000 & 0.000 \\
\hline Day 28 & $\begin{array}{l}79.33 \pm \\
2.34\end{array}$ & $\begin{array}{l}120.67 \pm \\
1.97\end{array}$ & 41.00000 & 0.000 \\
\hline
\end{tabular}

\section{DISCUSSION}

Due to common existence of diabetes and hypertension, oral hypoglycemic agents are often used along with antihypertensive drugs. Amlodipine is one of the frequently used drug for the management of hypertension. Among the sulfonylureas glibenclamide showed greater increase in insulin sensitivity than other drugs of the same class. ${ }^{20}$ About interaction between Glibenclamide and Amlodipine, opinions among different literatures are varied.

Similar to the study reported by B. Kishore Kumar Reddy et al. and Wofford MR, King DS et al. current study also showed no increase in FBG level due to Amlodipine in non-diabetic rats. ${ }^{16,20}$ however it contradicts with the findings of Naidu et al. ${ }^{21}$

Normal level of FBG was noted in Glibenclamide treated on $7^{\text {th }}$ day and the result was persistent throughout the study period. However, amlodipine and glibenclamide combination shows initial lowering of FBG level but raised values were observed on $21^{\text {st }}$ and $28^{\text {th }}$ day. This indicates probable pharmacodynamic interaction between amlodipine and glibenclamide in combination group.

Current study shows concomitant use of amlodipine with glibenclamide in the diabetic rats has blunting effect on the blood glucose lowering efficacy of glibenclamide, which was similar to the study reported by Prajapat $\mathrm{R}$ et al, Reddy KJ et al. ${ }^{22,23}$

Blunting of hypoglycemic effect of glibenclamide due to amlodipine may have following probable mechanism Glibenclamide act by inhibiting ATP sensitive $\mathrm{K}^{+}$ channels in the beta cells of pancreas. Inhibition of these $\mathrm{K}^{+}$channels induce depolarization of $\beta$ cell membrane which opens voltage sensitive $\mathrm{Ca}^{2+}$ channels leading to 
influx of calcium ions which stimulates the release of insulin. ${ }^{12}$ Amlodipine by blocking the $\mathrm{Ca}^{2+}$ channels in pancreatic beta cells may interfere with the insulin release which may cause hyperglycemia. ${ }^{24}$ In normal rats blockage of $\mathrm{Ca}^{2+}$ channel by using amlodipine may not produce hyperglycemia, decrease insulin secretion as the pancreas has healthy $\beta$ cell. It requires only $30 \%$ functioning $\beta$ - cell to maintain blood sugar level within normal limits. In our experimental model Type 2 diabetes is produced by using nicotinamide + streptozotocin injection which causes only partial destruction of pancreatic $\beta$ - cell pool. Diabetic rats treated with only amlodipine did not show worsening of hyperglycemia in the initial 2 weeks, may be due to the presence of residual healthy pancreatic $\beta$ - cells. But as the time progresses worsening of hyperglycemia that was observed could have been contributed by development of insulin resistance or down regulation of insulin receptors.

\section{CONCLUSION}

From the results of the study we can conclude that although amlodipine has no significant effect on the fasting blood glucose level in normal rats but it can cause significant worsening of hyperglycemia in diabetic rats. The co-administration of amlodipine with glibenclamide to the diabetic rats has blunting effect on the blood glucose lowering efficacy of glibenclamide. Current study warrants further work to find out the molecular level of interaction between these two drugs and the effect in actual clinical setting need to be explored.

Funding: No funding sources

Conflict of interest: None declared

Ethical approval: The study was approved by the Institutional Animal Ethics Committee of Rajendra Institute of Medical Sciences, (RIMS), Ranchi

\section{REFERENCES}

1. The Expert Committee on the Diagnosis and Classification of Diabetes Mellitus: Report of the Expert Committee on the Diagnosis and Classification of Diabetes Mellitus. Diabetes Care. Jan 2003,26(1):1183-97.

2. Melmed S, Polonsky KS, Reed Larsen PR, Kronenberg HM. Williams Textbook of Endocrinology. $12^{\text {th }} \quad$ Ed. Philadelphia: Elsevier/Saunders; 2011:1371-1435.

3. Atlas ID. International Diabetes Federation, Brussels, 2015. Available from: http://www.diabetesatlas.org/resources/2015atlas.html [Last accessed: 2nd April, 2017]

4. Staessen JA, Birkenhäger WH, Fagard RH. Dihydropyridine calcium-channel blockers for the treatment of hypertensive diabetic patients. 2000:2-7.

5. Wannamethee SG, Shaper AG, Lennon L, Morris RW. Metabolic syndrome vs Framingham Risk Score for prediction of coronary heart disease, stroke, and type 2 diabetes mellitus. Archives of Internal Medicine. 2005 Dec 12;165(22):2644-50.

6. Adler AI, Stratton IM, Neil HA, Yudkin JS, Matthews DR, Cull CA, et al. Association of systolic blood pressure with macrovascular and microvascular complications of type 2 diabetes (UKPDS 36): prospective observational study. Bmj. 2000 Aug 12;321(7258):412-9.

7. Chobanian AV, Bakris GL, Black HR, Cushman WC, Green LA, Izzo JL, et al. Seventh report of the joint national committee on prevention, detection, evaluation, and treatment of high blood pressure. hypertension. 2003 Dec 1;42(6):1206-52.

8. Makrilakis K, Bakris G. Diabetic hypertensive patients: improving their prognosis. Journal of cardiovascular pharmacology. 1998 Jan 1;31:S34-40.

9. Arauz-Pacheco C, Parrott MA, Raskin P. The treatment of hypertension in adult patients with diabetes. Diabetes care. 2002 Jan 1;25(1):134-47.

10. Cooper ME, Johnston CI. Optimizing treatment of hypertension in patients with diabetes. JAMA. 2000 Jun 28;283(24):3177-9.

11. May M, Schindler C. Clinically and pharmacologically relevant interactions of antidiabetic drugs. Therapeutic advances in endocrinology and metabolism. 2016 Apr 1;7(2):6983.

12. Martindale. The complete drug references. $36^{\text {th }}$ Ed. Vol.1, London: Pharmaceutical press; 2009:13421343.

13. Kaplan NM. Treatment of coexisting diabetes and hypertension. Current cardiology reports. 2001 Nov 1;3(6):498-503.

14. Kiienburg E, Schernthaner G. Metabolic Effects of Isradipine Versus Hydrochlorothiazide in Diabetes Mellitus. Hypertension. 1991;17(1):15-21.

15. Owolabi OJ, Omogbai EKI. Co-administration of Glibenclamide and Amlodipine Induces Resistance to Hyperglycemia Treatment in Streptozotocin induced Adapted/Non-adapted Diabetic rats; Clin Exp Pharmacol. 2011 Dec;1(1):102.

16. Wofford MR, King DS. Relationship between antihypertensive drugs and metabolic syndrome. Metabolic syndrome and related disorders. 2004 Sep 1;2(4):308-14.

17. Masiello P, Broca C, Gross R, Roye M, Manteghetti M, Hillaire-Buys D, et al. Experimental NIDDM: development of a new model in adult rats administered streptozotocin and nicotinamide. Diabetes. 1998 Feb 1;47(2):224-9.

18. Ghosh MN. Some standard Techniques, In: Ghosh $\mathrm{MN}$, editor, Fundamentals of Experimental Pharmacology, $5^{\text {th }}$ Ed. Kolkata: Hilton and Company 2011:15-16.

19. Medhi B, Prakash A. Dose calculation for experimental animal, In: Practical Manual of experimental and clinical Pharmacology, $1^{\text {st }}$ Ed. New Delhi: Jaypee Brothers Medical publishers; 2010:24.

20. Reddy BKK. A Study on Drug-Drug Interaction between Anti-Hypertensive Drug Combination 
Amlodipine and Telmisartan on Anti-Diabetic Effect of Glimepiride and Metformin in Normal and Streptozotocin Induced Diabetic Rats. JPBR. 2014;2(1):63-8.

21. Naidu SV, Suresha RN, Huralikuppi JC, Ashwini V, Satish AM, Brahadeesh M. Effect of Amlodipine on Oral Glucose induced Glycemic Changes in Normal Albino Rats. Int J Pharm Sci Res. 2012;3(9):3412-17.

22. Rani N, Sharma A, Singh R. Imidazoles as promising scaffolds for antibacterial activity: a review. Mini reviews in medicinal chemistry. 2013 Oct 1;13(12):1812-35.

23. Reddy KJ. Pharmacodynamic Interactions of Amlodipine and Enalapril with Glyburide in Normal and Diseased Rats. American Journal of Pharm Tech Research. 2016;6(2):504-29.

24. Bruton LL, Laso JS, Parker KL. Endocrine pancreas and pharmacotherapy of diabetes mellitus and hypoglycemia, Goodman and Gilman's, The Pharmacological basis of Therapeutics, 12 ${ }^{\text {th }}$ Ed. McGraw-Hill companies, 2011:1255-1257.

Cite this article as: Gari M, Debbarma RR, Majhee L, Choudhury S. Effect of amlodipine on blood glucose level in euglycemic and streptozotocin induced diabetic Albino rats and its

pharmacodynamic interaction with glibenclamide. Int J Basic Clin Pharmacol 2017;6:1650-4. 